\title{
ADSORBENT MATERIALS FOR EMERGING CONTAMINANT (TETRACYCLINE) REMOVAL
}

\author{
Denisse Morales-Serrato ${ }^{1,2}$, Jonatan Torres-Pérez ${ }^{1}$, Álvaro de Jesús Ruíz-Baltazar ${ }^{2}$ and \\ Simón Yobanny Reyes-López ${ }^{3}$ \\ ${ }^{1}$ Laboratorio de Transferencia y Degradación de Contaminantes, Instituto de Ciencias Biomédicas, Universidad Autónoma \\ de Ciudad Juárez, Envolvente del PRONAF y Estocolmo s/n, Ciudad Juárez, Chih., México, C. P. 32300, México \\ ${ }^{2}$ CONACYT-Centro de Física Aplicada y Tecnología Avanzada, Universidad Nacional Autónoma de México, Boulevard \\ Juriquilla 3001, Juriquilla las Mesas, Querétaro, QRO, CP 76230, México \\ ${ }^{3}$ Laboratorio de Materiales Híbridos Nanoestructurados, Instituto de Ciencias Biomédicas, Universidad Autónoma de Ciu- \\ dad Juárez, Envolvente del PRONAF y Estocolmo s/n, Ciudad Juárez, Chih., México, C. P. 32300, México
}
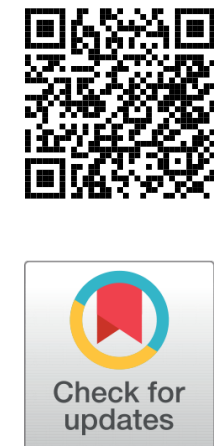

Received 1 April 2021

Accepted 14 April 2021

Published 30 April 2021

Corresponding Author

Simón Yobanny Reyes-López, simo

n.reyes@uacj.mx

DOI 10.29121/

granthaalayah.v9.i4.2021.3847

Funding: This research received no specific grant from any funding agency in the public, commercial, or not-for-profit sectors.

Copyright: (C) 2021 The Author(s). This is an open access article distributed under the terms of the Creative Commons Attribution License, which permits unrestricted use, distribution, and reproduction in any medium, provided the original author and source are credited.

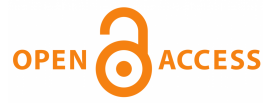

\section{ABSTRACT}

Water pollution is a serious environmental problem caused by anthropogenic activities. A group of pollutants that are not controlled in the environment but that cause harmful effects on the ecosystem are known as emerging pollutants. One of these groups of emerging pollutants detected in water bodies are pharmaceutical compounds. One of the main problems caused by pharmaceutical compounds as pollutant is bacterial resistance. Tetracyclines are a family of antibiotics frequently used. Due to their poor absorption they are released into the environment through feces and urine as active ingredients. Wastewater treatment consists in three stages: primary, secondary, and tertiary treatment. Tertiary treatment employs methods such as reverse osmosis, oxidationreduction, ultraviolet irradiation, and adsorption. Adsorption is used because it is a simple and effective. For the choice of an effective adsorbent material, surface area, porosity, adsorption capacity, mechanical stability, and factors such as profitability, regeneration, sustainability, and selectivity are considered. In the present review, the adsorbents commonly used in the treatment of water contaminated with tetracyclines were analyzed. The adsorbents used have been classified in a general way as metallic materials, polymers, ceramics, composites, and materials based on biomass.

Keywords: Wastewater Treatment, Adsorption, Emerging Pollutants, Tetracyclines, Adsorbent Materials

\section{INTRODUCTION}

Nowadays, water pollution is an important environmental problem. The pollution problem begins when some pollutants from anthropogenic activities are directly or 
indirectly discharged into the aquatic bodies Noreen (2019). Numerous chemical compounds and their by-products are often detected in water bodies around the world. The release of pollutants into freshwater ecosystems causes habitat degradation and loss of biodiversity Xiong et al. (2019). As a result, water quality is affected, because of that it is posed as a threat to ecosystems health Li et al. (2010). Pollutants detected in water bodies are mainly divided in two groups, inorganic and organic pollutants. Inorganic pollutants are in general heavy metals from aqueous waste streams from different industries, such as metal plating facilities, mining operations, and tanneries Ruff et al. (2015). Organic pollutants are pharmaceuticals compounds, industrial chemicals, dyes, pesticides, and their by-products. Pollutants are integrated in the environment through effluents from wastewater treatment plants and runoff from agricultural lands Piai et al. (2019).

Emerging pollutants are defined as synthetic or natural chemicals that are not constantly monitored in the environment, but they have the potential to cause negative effects on the ecosystem and human health. Various emerging pollutants, their metabolites, and their by-products have been found in water bodies. Emerging pollutants can be released from specific pollution sources like wastewater treatment plants in urban or industrial areas, from diffuse sources by atmospheric deposition or from agricultural and animal production. Emerging pollutants are classified into more than 20 classes related to their origin, among which are pharmaceuticals compounds, pesticides, disinfection by-products, wood preservation, and industrial chemicals Geissen (2015). In this review, it was discussed the main pollutants emerging from water bodies and the different adsorbent materials that have been used for the removal of tetracyclines which include metallic, ceramic, composite, polymer, and carbon-based materials. In addition, the different pollutant removal techniques that have been used were reviewed. Finally, some future considerations and advances in this research path will be highlighted.

\section{Pharmaceutical products}

Pharmaceutical compounds are stable chemical compounds created to improve human and animal health. Analgesics, anti-inflammatories, antibiotics, lipid regulators and beta-blockers are used in everyday life for diseases treatment Couto et al. (2019). The increase in the use of pharmaceutical products by both humans and animals leads to an increase in their presence in ecosystems. The pharmaceutical molecules reach aquatic bodies through human excretion, improper disposal, leaching from land, water drainage, or industry.

As a result of human activities, also antibiotic pharmaceutical products are detected in urban wastewater effluents, surface waters, groundwater, and hospital effluents Fatta-Kassinos et al. (2011). Conventional treatment methods do not eliminate all the antibiotic compounds; because of that, they are found in treated water at low concentrations in the $\mu \mathrm{g} / \mathrm{L}$ or ng/L range Luján-Facundo et al. (2019). Due to their toxicity and bacterial resistance, antibiotics represent a potential danger to aquatic species and to human health. 


\section{Antibiotics}

Antibiotics are the most widely used pharmaceutical compounds around the world due to their role in killing or inhibiting the growth of a wide group of microorganisms. They act as inhibitors of the synthesis of peptidoglycans (lactams, glycopeptides), protein synthesis (tetracyclines, chloramphenicol, mupirocin, macrolides, aminoglycosides-aminocyclitols) and the synthesis of nucleic acids by interrupting the metabolism of nucleotides (sulphonamides, diaminopyrimidinamines), or inhibit the DNA gyrase (quinolones). Some antibiotics (polymyxins) interfere with the integrity of the membrane. Large amounts of antibiotics are used in clinics and activities as agriculture, aquaculture, and livestock. After being used by humans and animals, approximately 10 to $90 \%$ of antibiotics are excreted through feces and urine as parental compounds or bioactive metabolites. Pharmaceutical products and their by-products take various routes to reach natural ecosystems Cheng (2019).

Antibiotics have received increasing attention as pollutants due to their widespread consumption and widespread occurrence in the environment. The presence of various classes of antibiotics has been reported in soils, sewage sludge, rivers, lakes and in drinking water. One of the main problems caused by antibiotics as pollutants in aquatic bodies is bacterial resistance, it affects people, health, veterinary and agriculture industries, which makes it one of the drawbacks of most urgent public health in the world. Bacterial resistance is defined as the ability that germs such as bacteria and fungi develop to defeat pharmaceutical compounds designed to kill them. Which means that bacteria and fungi do not die and continue their growing $C$ et al. (2020). Resistance to an antimicrobial agent can occurs through "intrinsic" or "acquired" mechanisms. Acquired resistance appears from the mutation or acquisition of various types of genetic material in the form of plasmids, transposons, and extra DNA chromosomal. Intrinsic resistance is a phenotype demonstrated by microorganisms prior to the use of an antimicrobial agent, that is mean a natural resistance property of the organism. Intrinsic resistance to antimicrobial agents is due to the nature and composition of the bacterial cell wall that can act as a permeability barrier, reducing the absorption of the compound, and also by constitutively synthesized enzymes that can cause the degradation of a compound Percival et al. (2005). Hence the importance for looking adsorbent materials for the removal of this type molecules from water, as is the specific case of tetracyclines.

\section{Tetracyclines}

Tetracyclines are a family of natural (tetracycline, oxytetracycline, and chlortetracycline) or synthetic (demeclocin, methacycline, minocycline, doxycycline, rolitetracycline, lymecycline, and tigecycline) antibiotics from various species of Streptomyces spp. They act against a wide spectrum of gram positive and gram negative bacteria, such as: Borrelia sp, Coxiella burnetti, T. pertenue, T. pallidum, Mycoplasma, Clamydia sp, Helycobacter pylori, Plasmodium sp, Rickettsia sp, E. histolytica and 
mycobacteria Pancorbo-Mendoza and Zegarra-Del-Carpio (2004), Vicente and PérezTrallero (2010). They are often used in humans and animals. Tetracyclines act by inhibiting the protein synthesis of different bacteria, adhere to the $30 \mathrm{~S}$ subunit of the bacterial ribosome and prevent the binding of the aminoacyl site of the transfer ribonucleic acid to the $30 \mathrm{~S}$ ribosomal subunit, thus preventing the integration of amino acids along the protein synthesis Vicente and Pérez-Trallero (2010).

\section{Classification and chemical structure of tetracyclines}

According to year of discovery, tetracyclines are divided in three groups or generations; First generation (1948-1963): Includes tetracycline, chlortetracycline, oxytetracycline, lymecycline, demeclocycline, methacycline, and rolitetracycline; Second generation (1965 - 1972): Doxycycline and minocycline are included and third generation (1993): They are semisynthetic analogs such as glycylcycline Vicente and Pérez-Trallero (2010). Tetracyclines have a nucleus with a linear structure consisting of four rings as can be seen in Table 1 and some examples of their main applications.

\begin{tabular}{|c|c|c|}
\hline Antibiotic & $\begin{array}{l}\text { IUPAC name and } \\
\text { chemical structure }\end{array}$ & Applications \\
\hline Tetracycline & Figure 1 & $\begin{array}{l}\text { Rickettsial infections, ehrlichiosis, anaplasmosis, } \\
\text { leptospirosis, amebiasis, actinomycosis, } \\
\text { nocardiosis, brucellosis, melioidosis, tularemia, } \\
\text { chlamydial infections, pelvic inflammatory } \\
\text { disease, syphilis, traveler's diarrhea, early Lyme } \\
\text { disease, acne, legionnaire's disease, Whipple } \\
\text { disease, rosacea, bullous dermatoses, } \\
\text { sarcoidosis, Kaposi sarcoma, pyoderma } \\
\text { gangrenosum, hidradenitis suppurativa, Sweet } \\
\text { syndrome, panniculitis, pityriasis, rheumatoid } \\
\text { arthritis, scleroderma, and cardiovascular } \\
\text { diseases [I and Nih (2020) ]. }\end{array}$ \\
\hline Chlortetracycline & Figure 2 & $\begin{array}{l}\text { In humans - allergic dermatitis. } \\
\text { In veterinary medicine - Conjunctivitis (dogs, } \\
\text { cats, and horses). Infected wounds (cattle, } \\
\text { sheep, and pigs). Respiratory infections (calves, } \\
\text { pigs and chickens) [Albert (1952) ]. }\end{array}$ \\
\hline Oxytetracycline & Figure 3 & $\begin{array}{l}\text { Clostridial wound infections and anthrax. } \\
\text { Infections of the respiratory and urinary tract, } \\
\text { skin, ears, eyes and gonorrhea, Legionnaires' } \\
\text { disease, urethritis, Lyme disease, brucellosis, } \\
\text { cholera, typhus, chlamydia and mycoplasma } \\
\text { infections [Albert (1952) ]. }\end{array}$ \\
\hline Demeclocycline & Figure 4 & $\begin{array}{l}\text { Pneumonia, infections of the skin, eyes. } \\
\text { Lymphatic, intestinal, genital, and urinary } \\
\text { systems, acne, plague and tularemia [Albert } \\
\text { (1952) ]. }\end{array}$ \\
\hline
\end{tabular}

Continued on next page 


\section{Table 1 continued}

\begin{tabular}{ccc}
\hline Methacycline & Figure 5 & $\begin{array}{l}\text { Methacycline has the same pharmacology as } \\
\text { tetracyclines, with fewer side effects [Albert } \\
\text { (1952) ]. }\end{array}$ \\
Foxycycline & $\begin{array}{r}\text { Doxycycline has the same pharmacology as } \\
\text { tetracyclines. It is long-lasting, more active } \\
\text { against pathogenic microorganisms [Albert } \\
\text { (1952) ]. }\end{array}$ \\
Finocycline & $\begin{array}{l}\text { Minocycline has the same pharmacology as } \\
\text { tetracyclines. It has secondary effects on the } \\
\text { vestibular apparatus [Albert (1952) ]. }\end{array}$ \\
\hline
\end{tabular}<smiles>CN(C)[C@H]1C(=O)C(C(N)=O)=C(O)[C@]2(O)CC1O[C@@]1(C)C(=C(O)c3c(O)cccc31)C2=O</smiles>

Figure 1 (4S,4aS,5aS,6S,12aR)-4-(dimethylamino)-1,6,10,11,12a-pentahydroxy-6-methyl-3,12dioxo-4,4a,5,5a-tetrahydrotetracene-2-carboxamide<smiles>CN(C)[C@H]1C(=O)C(C(N)=O)=C(O)[C@@]2(O)C(=O)C3=C(O)c4c(O)ccc(Cl)c4C(C)(O)C3C[C@H]12</smiles>

Figure 2 (4S,4aS,5aS,6S,12aR)-7-chloro-4-(dimethylamino)-1,6,10,11,12a-pentahydroxy-6methyl-3,12-dioxo-4,4a,5,5a-tetrahydrotetracene-2-carboxamide<smiles>CN(C)[C@H]1C(=O)C(C(N)=O)=C(O)[C@@]2(O)C(=O)C3=C(O)c4c(O)cccc4[C@@](C)(O)C3[C@H](O)[C@H]12</smiles>

Figure 3 (4S,4aR,5S,5aR,6S,12aR)-4-(dimethylamino)-1,5,6,10,11,12a-hexahydroxy-6-methyl3,12-dioxo-4,4a,5,5a-tetrahydrotetracene-2-carboxamide 
Figure $4 \quad(4 \mathrm{~S}, 4 \mathrm{aS}, 5 \mathrm{aS}, 6 \mathrm{~S}, 12 \mathrm{aR})-7$-chloro-4-(dimethylamino)-1,6,10,11,12a-pentahydroxy-3,12dioxo-4a,5,5a,6-tetrahydro-4H-tetracene-2-carboxamide<smiles>C=C1c2cccc(O)c2C(O)=C2C(=O)[C@]3(O)C(O)=C(C(N)=O)C(=O)[C@H](N(C)C)[C@H]3[C@H](O)[C@H]12</smiles>

Figure 5 (4S,4aR,5S,5aR,12aR)-4-(dimethylamino)-1,5,10,11, 12a-pentahydroxy-6-methylidene3,12-dioxo-4, 4a,5, 5a-tetrahydrotetracene-2-carboxamide<smiles>C[C@H]1c2cccc(O)c2C(O)=C2C(=O)[C@]3(O)C(O)=C(C(N)=O)C(=O)[C@H](N(C)C)[C@H]3[C@H](O)[C@H]21</smiles>

Figure $6 \quad(4 \mathrm{~S}, 4 \mathrm{aR}, 5 \mathrm{~S}, 5 \mathrm{aR}, 6 \mathrm{R}, 12 \mathrm{aR})-4$-(dimethylamino)-1,5,10,11, 12a-pentahydroxy-6-methyl3,12-dioxo-4a,5, 5a,6-tetrahydro-4H-tetracene-2-carboxamide<smiles>CN(C)c1ccc(O)c2c1CC1C[C@@H]3[C@@H](N(C)C)C(=O)C(C(N)=O)=C(O)[C@@]3(O)C(=O)C1=C2O</smiles>

Figure 7 (4S,4aS,5aR,12aR)-4,7-bis(dimethylamino)-1,10,11, 12a-tetrahydroxy-3,12-dioxo-4a,5, 5a,6-tetrahydro-4H-tetracene-2-carboxamide 
Due to their bactericidal properties, tetracyclines are widely used to enhance the growth of livestock as veterinary medicine and prevent infectious diseases in modern medical care. Due to their poor absorption and metabolism in vivo, tetracyclines can be transmitted directly to the environment by feces and urine as active ingredients Yuan (2019a). The presence of tetracyclines has been reported as micropollutants in the environment at concentrations of $0.13-0.51 \mu \mathrm{g} / \mathrm{L}$ in surface waters, $86-199 \mu \mathrm{g} / \mathrm{kg}$ in soils and $4.58 \mathrm{mg} / \mathrm{kg}$ in animal manure samples Yuan (2019b). The main effects that tetracyclines have on the environment and organisms are generalized in the damage to the functions and productivity of the ecosystem. Also, they have effects onto the induction of antibiotic resistance genes and the increase in the transfer of resistance genes through the food chain. Tetracycline species show high persistence and good solubility in water, leading to the inability to completely remove them from the water in wastewater treatment plants Yuan (2019a).

\section{Techniques for wastewater treatment}

Wastewater treatment consists on the contained organic mass separation. Water treatment aims to eliminate the greatest amount of pollutants Cabildo et al. (2008). Currently, the processes for wastewater treatment consist of three stages: primary, secondary, and tertiary or advanced treatment. Primary treatment consists in the elimination of insoluble matter present in wastewater through physicochemical procedures. This process includes $\mathrm{pH}$ neutralization treatments, separation and removal of oils and fats by flotation and sedimentation by centrifugation Cristóvão et al. (2014). Secondary treatment decreases biochemical oxygen demand (BOD) and chemical oxygen demand (COD) using biological processes. Most used secondary treatments are filters and activated sludge. Secondary treatments make use of bacteria and other microorganisms to break down organic pollutants. Water resulting from secondary treatment has a decrease of approximately $90 \%$ in BOD Cabildo et al. (2008). Tertiary or advanced treatment is applied to waters from the primary and secondary treatments. Its objective is to treat the water and achieve the highest possible purity before reincorporating it into the environment. Tertiary treatment employs the methods of reverse osmosis, electrodialysis, oxidation-reduction, ion exchange, precipitation, neutralization, coagulation, photodegradation, and ultraviolet irradiation and adsorption. Among the methods used, adsorption is one of the most used due to its high efficiency Luján-Facundo et al. (2019).

\section{Advanced oxidation}

Advanced oxidation processes (AOP) involve the production of hydroxyl radicals $(\mathrm{OH} \cdot)$ in large quantities to purify water. AOPs are applied for the destruction of organic and inorganic pollutants in water and wastewater. Hydroxyl radicals, as a powerful oxidizing agent, are expected to destroy pollutants in sewage and transform them into less toxic and even non-toxic products Deng and Zhao (2015).

\section{Advanced oxidation processes based on hydroxyl radicals}

Hydroxyl radical is the most reactive oxidizing agent in water treatment, it reacts rapidly with numerous species, it attacks organic pollutants through four ways: rad- 
ical addition, hydrogen abstraction, electron transfer and radical combination. Their reactions with organic compounds produce carbon-centered radicals ( $\mathrm{R} \cdot$ or $\mathrm{R} \cdot \mathrm{-OH}$ ). In the presence of $\mathrm{O}_{2}$, carbon-centered radicals can be transformed into peroxyl radicals (ROO). . All radicals react with the formation of more reactive species such as $\mathrm{H}_{2} \mathrm{O}_{2}$ and superoxide $\left(\mathrm{O}_{2} \bullet-\right)$, leading to chemical degradation and even mineralization of organic compounds. Because hydroxyl radicals have a short lifespan, they are only produced through different methods; in combination of oxidizing agents $\left(\mathrm{H}_{2} \mathrm{O}_{2}\right.$ and $\mathrm{O}_{3}$ ), irradiation (ultraviolet light or ultrasound) and catalysts $\left(\mathrm{Fe}^{2+}\right)$ Deng and Zhao (2015).

\section{Filtration}

Filtration is a process that separates particles of a certain size from treated wastewater. Separation processes are pressure driven and rely on diffusion or convection mass transfer phenomena to separate dissolved and suspended components from aqueous solutions. The filters used vary from one system to another depending on the condition of the entering water. It exists two main types of filtration in wastewater treatment systems: particle filtration and membrane filtration Coday et al. (2014).

Particulate filtration is a system that separates solids from liquids using physical or mechanical means. When it comes to wastewater treatment, particulate filtration is designed to remove solids that are more than one micron in size. Membrane filtration is commonly used when particulate filtration is not enough for water reuse. When it is required the highest quality of water, membrane filtration systems are used. Membrane filtration is a splitting process that uses a semi-permeable membrane to separate the stream into two fractions: a permeate that contains the material that passes through the membranes and a retentate that comprises the species that is left behind. Membrane filtration can be classified in terms of the size range of permeable species, driving forces employed, chemical structure, composition of membranes, and geometry of the construction. The most important types of membrane filtration are pressure-driven processes that include nanofiltration (NF), microfiltration (MF), ultrafiltration (UF), and reverse osmosis (RO) H. Zhou and Smith (2001). Next, adsorption technique will be deepened as it is the main topic of this manuscript.

\section{Adsorption}

Adsorption is a surface process, it occurs when a molecule, called adsorbate presents in a solution, adheres to the surface of a solid, called adsorbent, without diffusing into its structure. There are two types of adsorption; 1) Physical adsorption (physisorption) when adsorbate adheres to the surface due to physical forces such as Van der Waals interactions. 2) Chemical adsorption (chemisorption) if the adsorbate is chemically bound to the surface of the adsorbent, forming an actual chemical bond (usually covalent) with the surface of the adsorbent. Adsorption is used because it is a very simple, effective, inexpensive process, insensitive to toxic compounds and has regenerative capacity. It is an effective way to remove inorganic and organic pol- 
lutants from water in wastewater purification and treatment processes Kwon et al. (2011).

\section{Adsorption processes}

Through adsorption processes it is possible obtain information about the sorption mechanism and the maximum adsorption capacity of the used adsorbent. Adsorption processes can be carried out by two techniques: batch and continuous adsorption. Batch adsorption is performed on laboratory scale and therefore a small amount of wastewater can be treated. The obtained data from the batch adsorption process is not useful for application on an industrial scale. While the column or continuous adsorption process is preferred for industrial applications Sharififard et al. (2018).

To achieve that an adsorbent will be effective, parameters such as surface area, porosity, adsorption capacity, mechanical stability must be as high as possible along with the feasibility of factors such as cost effectiveness, easy regeneration, sustainability, and selectivity Yagub et al. (2014). Many adsorbents used in recent years are derived from agricultural, domestic, industrial wastes, polymers, organic and inorganic materials. But in most cases, adsorbents obtained from inexpensive materials have low adsorption efficiency Mashkoor et al. (2020).Therefore, it has become necessary to find more advanced, and effective adsorbent materials for the efficient treatment of wastewater.

\section{Materials}

Material is a set of elements with a unique composition and structure used for a specific purpose. Materials science has as its main objective the fundamental knowledge of the internal structure, properties, and preparation of materials. Properties that a material possesses are defined by the organization of its atoms Mercier et al. (2012). Materials science and engineering mainly classify them into metallic, polymeric, ceramic, and composite materials Smith and Hashemi (2006).

\section{Metals}

Metallic materials are inorganic compounds composed mostly of metallic elements such as $\mathrm{Fe}, \mathrm{Cu}, \mathrm{Al}, \mathrm{Mg}, \mathrm{Ni}, \mathrm{Ti}$, but they have non-metallic elements such as $\mathrm{Ca}, \mathrm{N}$, and $\mathrm{O}$. Metallic elements have a crystalline structure ordered by the arrangement of its atoms. Among their properties is that they are good thermal and electrical conductors, resistant and ductile at room temperature, high resistance even at high temperatures. Metals are used in a wide variety of industries, including biomedical, aeronautics, electronics, energetic, civil structures, and transportation Smith and Hashemi (2006).

\section{Nanoparticles}

Nanomaterials are materials that are small, less, or equal than $100 \mathrm{~nm}$, and therefore possess the unique property of an exceptionally high surface/volume ratio, offering faster adsorption and much higher removal efficiency of pollutants. Nanomaterials have been widely synthesized and used in the removal of pollutants from wastewater Gupta et al. (2017). Recently, research interest has been focused in nanostructured materials that are available in different forms; nanotubes, 
nanoparticles and nanowires. Nanoscience and nanotechnology have received a great attention in wastewater treatment, nanoadsorbents work quickly, penetrate deeply, and have excellent pollutant-binding capacity, thus treating wastewater more effectively Mashkoor et al. (2020).

Nanoparticles (NPs) are defined as ultra-fine materials with a dimension less than $100 \mathrm{~nm}$ Nowack and Bucheli (2007). Synthesis of nanoparticles is mainly divided into two methods; 1 ) The top down method involves the partitioning of mass solids into smaller fractions. The method involves chemical processes, grinding, and the volatilization of the solid followed by the condensation of the volatilized components, and 2) The bottom-up method manufactures nanoparticles from the condensation of atoms or molecular compounds in gaseous phase or in solution Rao et al. (2004). Nanoparticles possess the property of unique size which leads to a larger surface area compared to their volume. While the arrangement of their atoms increases their surface energy, directly reflecting on their characteristic reactivity Hassan et al. (2019). Nanoparticles have been used to remove persistent pollutants from the environment due to their adsorption capacities related their high specific surface areas and their reusability. NPs are adsorbents with a great capacity to adsorb antibiotics in water C. C. Lin and Lee (2019).

\section{Polymers}

Polymers are composed of extensive chains or molecular networks of organic compounds. Most polymers are not crystalline; however, some may have crystalline and non-crystalline regions. Due to their structure, they are not good materials for conducting electricity, they are good insulators, they have low densities and decomposition temperatures. Industries that work with polymers focus on the synthesis of alloys or polymer blends to suit specific applications in which no other element is appropriate on its own. Polymeric blends are used in power tool housings, automotive bumpers, sporting goods, and synthetic components of athletic track facilities, among others Smith and Hashemi (2006).

\section{Ceramics}

Ceramics are inorganic materials composed of metallic and non-metallic elements chemically united. Ceramics can be crystalline, non-crystalline, or a combination of both. Their properties are high hardness and resistance to high temperatures, they are brittle, with limited weight, resistance to wear, little friction, and insulating properties, which is why they are used in the melting of metals and in furnace linings. Applications of ceramic materials are in the aeronautical, metallurgical, biomedical, and automotive industries, among others Smith and Hashemi (2006).

\section{Aluminosilicates}

Aluminosilicates are materials formed by $\mathrm{TO}_{4}(\mathrm{~T}=\mathrm{Si}, \mathrm{Al})$ interconnected by oxygen atoms. Internal structure of the aluminosilicates is generated from this threedimensional framework built by the $\mathrm{SiO}_{4}$ and $\mathrm{AlO}_{4}$ tetrahedra. Size of the pores is within the range of $0.3-2 \mathrm{~nm}$, therefore they are classified as micropores. Its structure makes its physical and chemical properties unique Król et al. (2012). Alumi- 
nosilicates have defined cavities, high surface area, high molecular selectivity and adsorption capacity, chemical and thermal stability. Ion exchange capacity of aluminosilicates is an intrinsic property of all minerals, it is the result of the exchange of Si atoms in the crystalline structure of aluminosilicates for other available atoms Baile et al. (2019). The structure type defines the structural properties of the aluminosilicates, including the opening of the pores, structure of the cavities and channel. The opening of the pores of the aluminosilicates, composed of $\mathrm{T}$ atoms $(\mathrm{T}=\mathrm{Si}, \mathrm{Al})$ and connected oxygen atoms, is the entrance of a cavity or a channel where organic pollutants enter. Pores with more T atoms/oxygen atoms have larger sizes. The pore space of the aluminosilicates is divided into cavities and/or channels. Cavities are the polyhedral units of aluminosilicates, while channels are composed of joined polyhedral units. Aluminosilicate channels vary from straight to sinusoidal or wide to narrow. Surface area and size of the pores depend directly on the characteristics of the cavities and channels of the aluminosilicates Jiang et al. (2018).

Aluminosilicates properties are different according to the proportion of silica and aluminum content. Low silica aluminosilicates have excellent ion exchange capacity. In water treatment, low silica aluminosilicates can be applied for softening, ammonium removal and heavy metals such as zinc, nickel, copper, and cadmium removal. High silica aluminosilicates are manufactured industrially by replacing the aluminum content with silica Burton (2018). High silica zeolite powders have been shown to be effective adsorbents for the removal of pollutants of an organic nature from water, including pharmaceutical compounds, personal care products, and industrial chemicals Jiang et al. (2018).

\section{Zeolites}

Zeolites are crystalline aluminosilicates, their structure is negatively charged, and they can adsorb exchangeable cations such as $\mathrm{Na}^{+}, \mathrm{K}^{+}, \mathrm{Ca}^{2+} \mathrm{y} \mathrm{Mg}^{2+}$. They have a defined three-dimensional structure, composed of silicon and aluminum tetrahedra that share oxygen vertices. Their tetrahedral units can connect differently thus forming a wide range of structures. Zeolites are found in nature, in volcanic areas around the world, but they can also be synthesized Díaz (2017). Zeolites have a high specific surface area, high cation exchange capacity, high chemical stability, abundant reserves, and they are inexpensive. Natural zeolites have been widely used as adsorbents to remove pollutants from aqueous solutions. Zeolites are also widely used as catalysts, ion exchangers, molecular sieves, and adsorbents due to the possibility to encapsulate many small molecules in their channels Papa (2018).

\section{Clays}

Clays are aluminosilicates formed by small crystalline particles, they are inorganic materials composed of aluminum, silicon, water, and iron, they also contain certain metals in small amounts. Clay minerals, which include kaolinite, illite, vermiculite and montmorillonite belong to the group of phyllosilicates, they are composed of tetrahedral sheets of silica combined with octahedral sheets of aluminum. Phyllosilicate minerals are further classified 1:1 and 2:1 according to the layers of clay 
minerals that they contain (Figure 8 ). Clay minerals with a 1:1 layered structure are composed of a tetrahedral sheet and an octahedral sheet, and clays with a 2:1 layered structure are those in which an octahedral sheet it is between two tetrahedral sheets of silica Park et al. (2019). Kaolin group of clays in 1:1 layer, includes kaolinite, halloysite and dickite clays possessing low surface areas and adsorption capacities. The 2:1 clay mineral, which include montmorillonite, vermiculite, illite, muscovite, and chlorite, have significant surface areas and adsorption capacities. The intermediate layer of clay minerals that expands 2:1 hydrates and expands by the interaction with water, the expansion process is mainly due to the presence of exchangeable hydrated cations that can be intercalated in the intermediate layer of clay minerals and result in expansion of the basal spacing. However, the middle layer of non-expanding 2:1 layered clay mineral is not enlarged by the presence of water because the $\mathrm{K}^{+}$is tightly bound in the middle layer, blocking water molecules from intercalating. As a result, the basal spacing is smaller, like that of the illite Park et al. (2019).

a)

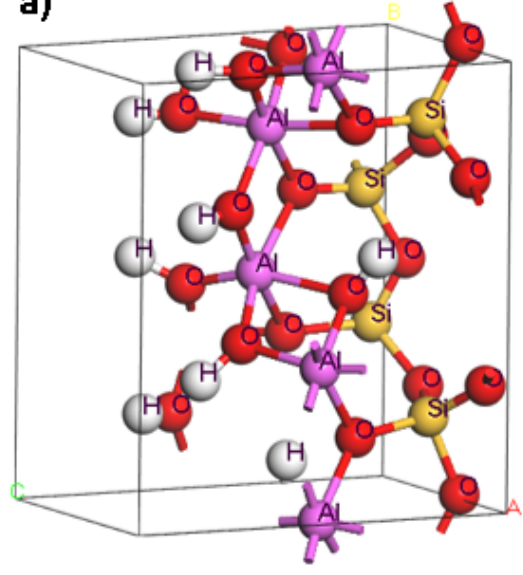

b)

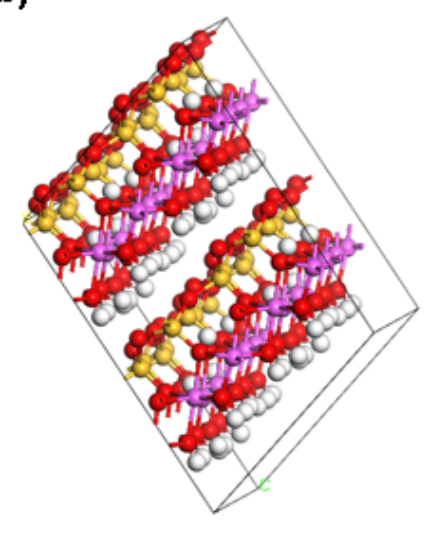

Figure 8 Clay structure a) Unit cell and b) supercell 2X2X2.

\section{Compounds}

A composite material is formed by two or more materials that make up a new one. Each material preserves its properties, and the new compound will have different properties than each material. Composite materials are made up of a specific filler material and a binder resin that aims to obtain the required properties and characteristics. Materials that make up the new compound do not dissolve among themselves and they are physically identified by the interface found between each material. There are different combinations of matrix and reinforcement materials that are used to generate the composites, as can be seen in Figure 9 . The matrix used in the composite material classifies it as: composite of metallic, ceramic, or polymeric matrix. The combinations of materials used in the creation of composites depend primarily on the application and the medium in what it will be used Smith and Hashemi 
(2006).
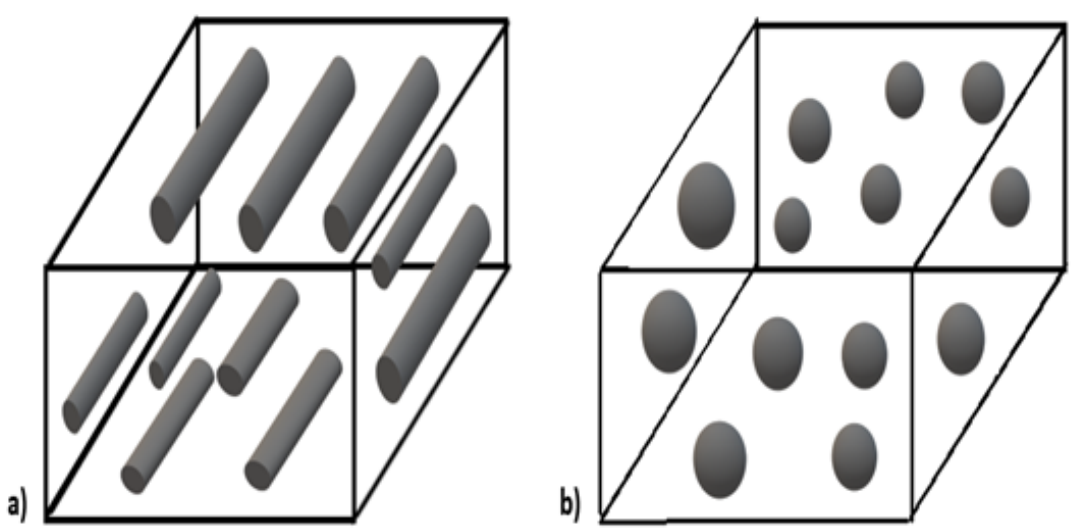

Figure 9 Composite materials a) matrix with continuous fiber reinforcement, b) matrix with particle reinforcement

\section{Biomass-based materials}

Carbon-based materials are considered as one of the most promising and effective adsorbents, they have been widely used for the removal of various pollutants, due to their large surface area, pore structure, texture characteristics and high adsorption capacity. Carbon-based materials have as advantages over other materials a high adsorption capacity, and chemical / thermal stability. Various types of carbonaceous materials have been used for the adsorption of antibiotics from water J. Dai (2018).

\section{Activated carbon}

Activated carbon is a common term used to describe carbon-based materials that have developed a large surface area, an internal porous structure (pores with a diverse size distribution), as well as a broad spectrum of oxygenated functional groups. An important characteristic of activated carbons is the wide variety of carbon precursor materials; physicochemical characteristics, in addition to the preparation method, they are responsible for the properties, textural characteristics and the possible applications of activated carbons. Interesting precursors have been used from wood and woody biomass, herbaceous and agricultural residues, industrial biomass residues and mixtures. Recently, biomass-based porous coals have attracted great attention due to low cost, abundance, renewable and ecological starting resource. Some of the most used natural precursors are coconut shells, pistachio shells, coffee residues and sugarcane bagasse J. Dai (2018).

For the manufacture of activated carbon various parts of plants are used including the nucleus, stems, husks, flowers, fruits, seeds, bones, and leaves. Recently, the use of aquatic biomass, fibers, grass, starch, and other unconventional precursors are more often described as activated carbon precursors. The production of activated carbon from lignocellulosic biomass has the advantages that the precursors are diverse, abundant and renewable, the synthesis is a relatively simple process due 
to the high reactivity of the biomass and it contributes to reduce the costs of waste disposal and the harmful effect on the environment González-García (2018).

Activated carbon is in general prepared at two stages, first, the carbonization of the carbonaceous raw material is treated under inert atmosphere at temperatures below $800^{\circ} \mathrm{C}$ and, second, the activation of the carbonized product. In the first stage, the cross-bonds between the carbon atoms are broken in the absence of oxygen. During the activation process, an improvement in porosity occurs by cleaning the pores. The main pores produced in the carbonization and activation process of activated carbons with natural precursors are micropores J. Dai (2018).

\section{Carbon nanotubes}

The most used nanoadsorbents for antibiotics removal from wastewater are carbon nanotubes (CNTs). Carbon nanotubes are nanomaterials that have high thermal and chemical stability, large surface/volume ratio, well-defined adsorption sites, easy attachment of functional groups, and the ability to be modified. Carbon nanotubes are one of the most studied nanomaterials as adsorbents due to their hollow and layered structure and their large specific surface area $\left(150-1500 \mathrm{~m}^{2} \cdot \mathrm{g}^{-1}\right) \mathrm{Yu}$ (2014).

a)

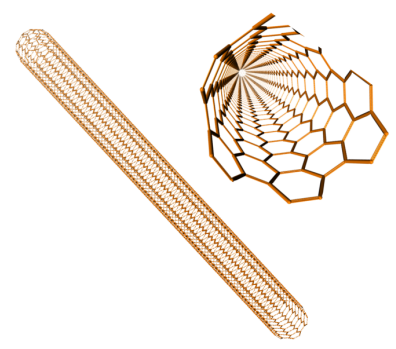

b)

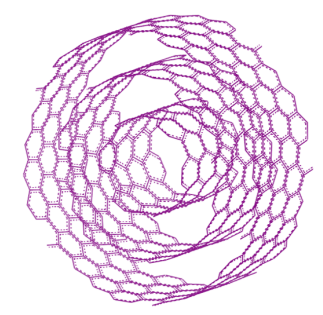

Figure 10 Carbon nanotubes: a) Single-walled carbon nanotubes and b) Multi-walled carbon nanotubes.

Carbon nanotubes consist in a sheet of graphene or graphite rolled into a tubular shape with a range of diameter and nanometric length, its final side are covered by a hemisphere of the fullerene-type structure. CNTs show a distinct curvature of the side wall and they are highly hydrophobic. The hollow and layered structure of CNTs offers a large surface area and higher porosity. The structure of carbon nanotubes possesses great mechanical resistance, electronic and thermal stability Aqel et al. (2012).

There are two types of carbon nanotubes: 1) Single-walled carbon nanotubes and 2) Multi-walled carbon nanotubes (Figure 10 ). Single-walled carbon nanotubes are made up of a single graphene sheet rolled into a cylindrical shape, whereas multiplewalled carbon nanotubes consist of the concentric stacking of two or more cylindershaped graphene sheets and the adjacent sheet is it is joined by Van der Waals forces with an intermediate space of approximately 0.34 nm Aqel et al. (2012). Carbon nan- 
otubes contain functional groups such as $-\mathrm{OH},-\mathrm{C}=\mathrm{O}$, and $-\mathrm{COOH}$, depending on the synthesis procedure and the purification process. Electrostatic interactions are those that predominate in the adsorption of ionic compounds due to the surface charge of carbon nanotubes D. Lin and Xing (2008).

\section{Materials used as adsorbents for tetracyclines}

The adsorbents commonly used in the treatment of polluted water are natural or the product of a synthetic process. The most used natural adsorbents are clays, aluminosilicates, or biopolymers. Engineering adsorbents can be classified into carbonaceous and polymeric adsorbents. Generally, engineered adsorbents exhibit higher adsorption capacities and they are produced under strict quality conditions, thus showing constant properties Worch (2012). There are different categories of adsorbents that have been investigated and used for the treatment of polluted water with antibiotics such as tetracyclines. Adsorbents have been classified in a general way as: metallic materials, polymers, ceramics, biomass-based materials, and composites X. Zhang et al. (2019).

Metallic materials have been used in the adsorption of tetracyclines, Zhang et al. (2019) prepared microspheres of phenolic hydroxyl functionalized copper alginate for tetracycline adsorption, synthesized the metallic material through a gelling and solidification process. The prepared adsorbent showed a maximum adsorption capacity $\left(\mathrm{q}_{e}\right)$ of $153.89 \mathrm{mg} / \mathrm{g}$ X. Zhang et al. (2019). Binary and ternary metal hydroxides based on copper, manganese and aluminum have also been used, CuMnAl hydroxide demonstrated a better removal of tetracycline from aqueous medium Eniola et al. (2020).

Some polymers used in the tetracyclines adsorption include chitosan, with a maximum adsorption capacity of $20 \mathrm{mg} / \mathrm{g}$, equilibrium was reached relatively quickly at 120 min Oladoja et al. (2014). Zhang et al. (2018) prepared virgin bleached polystyrene foams as adsorbents, they found better adsorption using bleached foams compared to virgin foams H. Zhang (2018). Benzimidazole-based hyper-crosslinked polymers (HCP) have been synthesized by a Friedel-Crafts reaction for the adsorption of chlortetracycline. HCPs provide considerable surface area and the channels they possess allow mass transfer, facilitating contact between active sites and chlortetracycline molecules. The maximum adsorption capacity reached was 456 mg/g L. Zhang et al. (2020).

Ceramics commonly used as adsorbents for antibiotics include materials such as double-layer hydroxide (LDH). LDHs are anionic clays that have been widely used and modified to achieve better adsorption of tetracyclines. Bouaziz et al. (2018) used a $\mathrm{Zn}_{2-} \mathrm{Al} \mathrm{LDH}$ material following the coprecipitation and anion exchange methods Bouaziz et al. (2018). Soori et al. (2016) mention that the intercalation of antibiotics occurs within the layers of the double layer hydroxide, and the reported $\mathrm{q}_{e}$ reaches $98.04 \mathrm{mg} / \mathrm{g}$ Soori et al. (2016). Other ceramics materials used in the adsorption of tetracyclines are zeolites and clays; Zou et al. (2012) modified a zeolite with $\mathrm{HCl}$, the modification carried out showed an adsorption capacity greater than that 
of natural zeolite Zou et al. (2012). Used clays include montmorillonite and Namontmorillonite Figueroa et al. (2004), illite, Bansal (2013), and kaolinite Li et al. (2010). Wu et al. (2020) modified the sepiolite (SEP) surface with cetyltrimethylammonium bromide (CTAB) and sodium dodecylbenzene sulfonate (SDBS) to obtain an organic sepiolite (C-S-SEP). The results showed that the adsorption capacity and removal rate of oxytetracycline (OTC) was $99.42 \%$ Wu et al. (2020). Ceramics such as modified alumina (SMA) with a surfactant (sodium dodecyl sulfate) have also been used in the adsorption of OTC, achieving 97\% removal of tetracyclines Pham et al. (2019).

It has been used functionalized silica nanoparticles (MSN) with cetyltrimethylammonium bromide (CTAB), synthesized from the sol-gel method, obtaining a $\mathrm{q}_{e}$ of $449.89 \mathrm{mmol} / \mathrm{g}$ Saman et al. (2020). Another ceramic material used is hydroxyapatite, Yuan et al. (2019) used nanohydroxyapatite (nHAP) for the removal of oxytetracycline. The results showed that the adsorption process reached equilibrium around 120 min Yuan (2019a). Harja and Ciobanu (2018) used hydroxyapatite nanopowders synthesized by the wet precipitation method using orthophosphoric acid and calcium hydroxide as raw materials, obtaining oxytetracycline removal rates of approximately $97.58 \%$ and $89.95 \%$ for calcined and uncalcined nanohydroxyapatites, respectively Harja and Ciobanu (2018).

Biomass-based materials are the most used materials as adsorbents, biochar materials from rice husk modified with methanol have been used Jing et al. (2014), tubular honeycomb biochar (HT-B) from fargesia leaves Ma (2018), biochar derived from rice straw (R) and pig manure (M) pyrolyzed at $400{ }^{\circ} \mathrm{C}(\mathrm{R} 400$ and $\mathrm{M} 400)$ and $600^{\circ} \mathrm{C}$ (R600 and M600) H. Wang (2018), acid and alkali modified biochar P. Liu et al. (2012), biochar produced from biomass residues Jia (2013), raw and activated pine wood biochar for the removal of chlortetracycline Taheran et al. (2016) and bamboo charcoal (BC) Liao (2013).

Activated carbons with different chemical natures have been used in the adsorption of tetracyclines Rivera-Utrilla et al. (2013). Microwave heated activated carbon fibers (WACF) at $600{ }^{\circ} \mathrm{C}$ in a nitrogen atmosphere $\left(\mathrm{N}_{2}\right)$ have shown a maximum adsorption capacity of $312.5 \mathrm{mg} / \mathrm{g}$ Huang et al. (2013). Graphene is widely used in the adsorption of antibiotics, Lin et al. (2013) prepared magnetic particles functionalized with graphene oxide (GO-MP) and natural graphene to be used as tetracycline adsorbents Y. Lin et al. (2013). Graphene oxide (GO) has a reported maximum adsorption capacity of $313 \mathrm{mg} / \mathrm{g}$ Gao (2012). Multi-walled carbon nanotubes (MWCNT) have been used for the adsorption of tetracycline. The adsorption efficiency has reached $99.8 \%$ and the maximum adsorption capacity reported was $269.54 \mathrm{mg} / \mathrm{g}$ L. Zhang et al. (2011).

Live and dead biomass materials from the microalgae Phaeodactylum tricornutum have also been used. Living biomass showed greater efficiency than dead biomass, showing maximum sorption capacities of $29.18 \mathrm{mg} / \mathrm{g}$ and $4.54 \mathrm{mg} / \mathrm{g}$, respectively Santaeufemia et al. (2016). 
Currently, the attention of researchers has focused on the creation of composite materials to be used as efficient adsorbents. Bovine serum albumin (BSA) is a protein that has been used as support for magnetic nanoparticles $\left(\mathrm{Fe}_{3} \mathrm{O}_{4}\right)$ to synthesize the compound of magnetic microspheres $\left(\mathrm{BSA} / \mathrm{Fe}_{3} \mathrm{O}_{4}\right)$, used for the removal of antibiotics. The compound was tested on four antibiotics (erythromycin, streptomycin, tetracycline, and chloramphenicol) and obtained antibiotic adsorption capacities ranging from 69.35 to $147.83 \mathrm{mg} / \mathrm{g}$ B. Zhang (2013).

Mesoporous silicates have been modified with iron by $\mathrm{Vu}$ et al. (2010) for the removal of tetracycline, obtaining a maximum adsorption capacity of $41.7 \mathrm{mg} / \mathrm{g} \mathrm{Vu}$, Shin, et al. (2010). Raeiatbin and Açlkel (2017) prepared chitosan nanoparticles modified with iron oxide nanoparticles (Fe304), obtaining a $\mathrm{q}_{e}$ of tetracycline of $78.11 \mathrm{mg} / \mathrm{g}$ Raeiatbin and Açıkel (2017). Zhang et al. (2017) synthesized a magnetic nanocomposite of $\mathrm{Fe}_{3} \mathrm{O}_{4} @$ graphene $\left(\mathrm{Fe}_{3} \mathrm{O}_{4} @ \mathrm{G}\right)$ using an in-situ precipitation method for the removal of oxytetracycline and tetracycline. The removal efficiency of $\mathrm{Fe}_{3} \mathrm{O}_{4} @ \mathrm{G}$ was measured in lake, tap and pool water, obtaining removal percentages of $95.45,96.68$ and $89.82 \%$ for oxytetracycline, and $98.77,98.23$ and $89.09 \%$ for tetracycline, respectively Y. Zhang (2017). Clay materials such as double layer hydroxide (LDH) have been modified to synthesize the Zn/Fe LDH compound. The composite material obtained a tetracycline removal percentage of $77.23 \%$ Zaher et al. (2020). Sugarcane bagasse is an agricultural residue used by Rattanachueskul et al. (2017) to create a magnetic carbon compound that exhibited a maximum adsorption capacity of $48.35 \mathrm{mg} / \mathrm{g}$ Rattanachueskul et al. (2017).

Zhou et al. (2012) prepared a Q100 hyperreticulated magnetic resin with a specific surface area of $1153.8 \mathrm{~m}^{2} / \mathrm{g}$, with a $\mathrm{q}_{e}$ of $178.20 \mathrm{mg} / \mathrm{g}$ Q. Zhou et al. (2012). Mohammed and Kareem (2019) used pistachio shell coated with ZnO nanoparticles (CPS) to remove tetracycline from wastewater. They achieved a $\mathrm{q}_{e}$ of $95.06 \mathrm{mg} / \mathrm{g}$ under conditions of $\mathrm{pH}=4$, dose $=0.08 \mathrm{~g} / \mathrm{mL}$, particle size $=87 \mathrm{~mm}$, stirring speed $=150 \mathrm{rpm}$ at $25^{\circ} \mathrm{C}$ Mohammed and Kareem (2019).

Nguyen et al. (2020) prepared polyvinylidene fluoride (PVDF)/polyaniline (PANI) -montmorillonite (MT) (PVDF/PANI/MT) mixed matrix porous membranes using an induced phase inversion method. The results obtained show that the PVDF/PANI/MT membrane with $20 \%$ by weight of PVDF, $5 \%$ by weight of PANI and 12 $\%$ by weight of MT achieved the highest removal of tetracycline Nguyen et al. (2020). Belaib et al. (2014) used peanut shells coated with polyaniline. The results confirmed the effectiveness of the adsorption process using the matrix for the decontamination of tetracyclines from aqueous environments with a qe of $65.6 \mathrm{mg} / \mathrm{g}$ Belaib et al. (2014).

Liang et al. (2019) used a biochar compound (CLB), montmorillonite (MMT) biochar compound (MBC) and MMT-biochar magnetic compound (MMBC), through pyrolysis and a mixture of $\mathrm{FeCl}_{3}$. Oxytetracycline adsorption experiments indicated that the maximum adsorption capacity of MMBC was $58.85 \mathrm{mg} / \mathrm{g}$ Liang (2019). Table 2 shows the used materials with their respective maximum adsorption capacity $\left(\mathrm{q}_{e}\right)$. 
Table 2 Comparison of the maximum adsorption capacities $\left(q_{e}\right)$ of tetracyclines with various types of adsorbents found in the literature

\begin{tabular}{|c|c|c|c|}
\hline Adsorbent & Adsorbate & qe (mg/g) & Reference \\
\hline Biochar $\mathrm{MeOH}$ & Tetracycline & 101.01 & $\begin{array}{c}\text { [Vicente and } \\
\text { Pérez-Trallero (2010) ] }\end{array}$ \\
\hline $\begin{array}{l}\text { Honeycomb tubular } \\
\text { biochar }\end{array}$ & Tetracycline & 123.60 & [Ma (2018) ] \\
\hline $\mathrm{BSA} / \mathrm{Fe} 304$ & Tetracycline & 104.35 & [B. Zhang (2013) ] \\
\hline $\begin{array}{c}\text { Fe-impregnated } \\
\text { mesoporous silicates }\end{array}$ & Tetracycline & 41.70 & [Vu, Shin, et al. (2010) ] \\
\hline Chitosan nanoparticles & Tetracycline & 78.11 & $\begin{array}{l}\text { [Raeiatbin and Açıkel } \\
\text { (2017) ] }\end{array}$ \\
\hline CA-BT & Tetracycline & 153.89 & [X. Zhang et al. (2019) ] \\
\hline Mg/Al-LDH & $\begin{array}{l}\text { Tetracycline } \\
\text { hydrochloride }\end{array}$ & 98.04 & [Soori et al. (2016) ] \\
\hline Chitosan & $\begin{array}{l}\text { Tetracycline } \\
\text { hydrochloride }\end{array}$ & 20.0 & [Oladoja et al. (2014) ] \\
\hline $\begin{array}{l}\text { Magnetic graphene } \\
\text { Fe304 }\end{array}$ & $\begin{array}{l}\text { Tetracycline } \\
\text { hydrochloride }\end{array}$ & 424.0 & [Y. Zhang (2017) ] \\
\hline Zn2-Al LDH & $\begin{array}{l}\text { Tetracycline } \\
\text { hydrochloride }\end{array}$ & 116.0 & [Bouaziz et al. (2018) ] \\
\hline Zn/Fe/La LDH (4:1:0.2) & $\begin{array}{l}\text { Tetracycline } \\
\text { hydrochloride }\end{array}$ & 170.53 & [Zaher et al. (2020) ] \\
\hline Red soil (RS) & Tetracycline & 12.0 & $\begin{array}{c}\text { [Y. J. Wang et al. (2010) } \\
\text { ] }\end{array}$ \\
\hline HCl-modified zeolite & Tetracycline & 20.4 & [Zou et al. (2012) ] \\
\hline Bamboo charcoal & Tetracycline & 23.5 & [Liao (2013) ] \\
\hline Graphene & Tetracycline & 39.1 & [Y. Lin et al. (2013) ] \\
\hline Montmorillonite & Tetracycline & 54.0 & [Figueroa et al. (2004) ] \\
\hline $\begin{array}{l}\text { Pistachio shell coated } \\
\text { with } \mathrm{ZnO} \text { nanoparticles } \\
\text { (CPS) }\end{array}$ & Tetracycline & 95.06 & $\begin{array}{l}\text { [Mohammed and } \\
\text { Kareem (2019)] }\end{array}$ \\
\hline Montmorillonite - Na & Tetracycline & 49.3 & [Figueroa et al. (2004) ] \\
\hline Graphene oxide & Tetracycline & 313.5 & [Gao (2012) ] \\
\hline Kaolinite & Tetracycline & 4.0 & [Li et al. (2010) ] \\
\hline Biochar R400 & Tetracycline & 8.25 & [H. Wang (2018) ] \\
\hline Biochar R600 & Tetracycline & 14.2 & \\
\hline Biochar M400 & Tetracycline & 6.5 & \\
\hline Biochar M600 & Tetracycline & 8.1 & \\
\hline La10MCM-41 & Tetracycline & 303.3 & $\begin{array}{l}\text { [Vu, Snisarenko, et al. } \\
\text { (2010) ] }\end{array}$ \\
\hline PVDF & Tetracycline & 1.4 & [Nguyen et al. (2020) ] \\
\hline PVDF/PANI & Tetracycline & 3.9 & \\
\hline PVDF/MT & Tetracycline & 25.1 & \\
\hline PVDF/PANI/MT & Tetracycline & 51.0 & \\
\hline $\begin{array}{l}\text { Sugarcane Bagasse } \\
\text { Magnetic Compound }\end{array}$ & Tetracycline & 48.40 & $\begin{array}{c}\text { [Rattanachueskul et al. } \\
\text { (2017) ] }\end{array}$ \\
\hline $\begin{array}{c}\text { Alkaline Biological } \\
\text { Carbon }\end{array}$ & Tetracycline & 58.80 & [P. Liu et al. (2012) ] \\
\hline
\end{tabular}




\begin{tabular}{|c|c|c|c|}
\hline Table 2 continued & & & \\
\hline SCG-1 & Tetracycline & 64.89 & [Y. Dai (2019) ] \\
\hline SCG-2 & Tetracycline & 123.46 & \\
\hline NDA150 & Tetracycline & 178.20 & [Q. Zhou et al. (2012) ] \\
\hline $\begin{array}{c}\text { Multi-walled carbon } \\
\text { nanotubes }\end{array}$ & Tetracycline & 269.50 & [L. Zhang et al. (2011) ] \\
\hline A-MCM-41 & Tetracycline & 415.10 & [M. Liu et al. (2013) ] \\
\hline $\begin{array}{c}\text { Graphene Oxide } \\
\text { Magnetic Nanoparticles }\end{array}$ & Oxytetracycline & 45.0 & [Y. Lin et al. (2013) ] \\
\hline Activated sludge & Oxytetracycline & 90.9 & [Song et al. (2014) ] \\
\hline $\begin{array}{l}\text { Maize-straw-derived } \\
\text { biochar }\end{array}$ & Oxytetracycline & 1.67 & [Jia (2013) ] \\
\hline $\begin{array}{l}\text { Peanut shells coated } \\
\text { with polyaniline }\end{array}$ & Oxytetracycline & 65.5 & [Belaib et al. (2014) ] \\
\hline $\begin{array}{l}\text { Surfactant-modified } \\
\text { alumina (SMA) }\end{array}$ & Oxytetracycline & 143.0 & [Pham et al. (2019) ] \\
\hline $\begin{array}{l}\text { Silica } \\
\text { MSN } \\
\text { FSN }\end{array}$ & $\begin{array}{l}\text { Oxytetracycline } \\
\text { Oxytetracycline }\end{array}$ & $\begin{array}{r}223.39 \\
8.33\end{array}$ & [Saman et al. (2020) ] \\
\hline Fe-N, N-SBA15 & Oxytetracycline & 70.99 & $\begin{array}{l}\text { [Saha and Chowdhury } \\
\text { (2011)] }\end{array}$ \\
\hline $\begin{array}{l}\mathrm{Zn} / \mathrm{Fe} \text { double layer } \\
\text { hydroxide }\end{array}$ & Oxytetracycline & 90.73 & [Zaher et al. (2020) ] \\
\hline $\begin{array}{l}\text { Hydroxide of: } \\
\text { CuAl } \\
\mathrm{MnAl} \\
\text { CuMnAl }\end{array}$ & $\begin{array}{l}\text { Oxytetracycline } \\
\text { Oxytetracycline } \\
\text { Oxytetracycline }\end{array}$ & $\begin{array}{l}123.50 \\
26.70 \\
172.40\end{array}$ & [Eniola et al. (2020) ] \\
\hline $\begin{array}{l}\text { Sepiolite (SEP) } \\
\text { CTAB-SDBS-SEP }\end{array}$ & $\begin{array}{l}\text { Oxytetracycline } \\
\text { Oxytetracycline }\end{array}$ & $\begin{array}{l}21.82 \\
41.28\end{array}$ & [Wu et al. (2020) ] \\
\hline $\begin{array}{l}\text { CLB } \\
\text { MBC } \\
\text { MMBC } \\
\text { CLAC }\end{array}$ & $\begin{array}{l}\text { Oxytetracycline } \\
\text { Oxytetracycline } \\
\text { Oxytetracycline } \\
\text { Oxytetracycline }\end{array}$ & $\begin{array}{c}22.39 \\
55.77 \\
58.85 \\
1340.82\end{array}$ & [Liang (2019) ] \\
\hline Nano-hydroxyapatite & Oxytetracycline & 78.27 & [Yuan (2019b) ] \\
\hline $\begin{array}{c}\text { Uncalcined } \\
\text { hydroxyapatite } \\
\text { Calcined hydroxyapatite }\end{array}$ & $\begin{array}{l}\text { Oxytetracycline } \\
\text { Oxytetracycline }\end{array}$ & $\begin{array}{l}291.32 \\
278.27\end{array}$ & $\begin{array}{l}\text { [Harja and Ciobanu } \\
\text { (2018) ] }\end{array}$ \\
\hline $\begin{array}{c}\text { Polystyrene foam (PS) } \\
\text { Beached foams }\end{array}$ & $\begin{array}{l}\text { Oxytetracycline } \\
\text { Oxytetracycline }\end{array}$ & $\begin{array}{l}1.52 \\
27.50\end{array}$ & [H. Zhang (2018) ] \\
\hline $\begin{array}{l}\text { Live biomass of the } \\
\text { microalga } \\
\text { Dead biomass of the } \\
\text { microalga }\end{array}$ & $\begin{array}{l}\text { Oxytetracycline } \\
\text { Oxytetracycline }\end{array}$ & $\begin{array}{r}29.18 \\
4.54\end{array}$ & $\begin{array}{l}\text { [Santaeufemia et al. } \\
\text { (2016) ] }\end{array}$ \\
\hline $\begin{array}{c}\text { Commercial activated } \\
\text { carbon }\end{array}$ & Oxytetracycline & 413.20 & $\begin{array}{l}\text { [Rivera-Utrilla et al. } \\
\qquad \text { (2013) ] }\end{array}$ \\
\hline Activated carbon fiber & Oxytetracycline & 312.50 & [Huang et al. (2013) ] \\
\hline Illite & Oxytetracycline & 8.85 & [Bansal (2013) ] \\
\hline $\begin{array}{l}\text { Alkali Treated Pine } \\
\text { Wood Biochar }\end{array}$ & Chlortetracycline & 434.8 & [Taheran et al. (2016) ] \\
\hline
\end{tabular}


Table 2 continued

Polymers HCPS
Chlortetracycline
456.0

[L. Zhang et al. (2020)]

\section{CONCLUSION}

Tetracyclines are a class of antibiotics widely used around the world, the abusive use of tetracyclines in veterinary and human medicine causes important affectations to the environment, being a threat to aquatic organisms, the ecosystem and human health. Residual concentration of tetracyclines in the environment has increased considerably due to their multiple applications and the inability of wastewater treatments to eliminate antibiotics. Numerous studies have been carried out using the adsorption technique for the removal of the different tetracyclines in aqueous media using various types of adsorbents that were classified as metallic, polymeric, ceramic, composite, and biomass-based materials. In most studies, materials such as clays, zeolites, magnetic composite soils, graphene, biochar, activated carbons and carbon nanotubes have been used as adsorbents. The adsorption capacity of tetracyclines was very different from one adsorbent to another, studies indicate that synthetic materials have better adsorption properties because they are conferred high surface area, surface charges and controlled morphologies to mention a few. Currently, adsorption studies are focused on the use of natural adsorbents such as soils, clays, and minerals, however, for effective wastewater treatment, advanced methodologies and synthetically designed adsorbents provide a better solution for tetracyclines removal.

\section{ACKNOWLEDGEMENTS}

Thanks to PRODEP, Universidad Autónoma de Ciudad Juárez and CONACYT.

\section{REFERENCES}

Albert, A. (1952). Selective toxicity. Lect. Sci. Basis Med, 2, 14-28.

Aqel, A., El-Nour, K. M. A., Ammar, R. A., \& Al-Warthan, A. (2012). Carbon nanotubes, science and technology part (I) structure, synthesis and characterisation. Arabian Journal of Chemistry, 5(1), 1-23. Retrieved from https://dx.doi.org/10.1016/j.arabjc.2010.08 .022 10.1016/j.arabjc.2010.08.022

Baile, P., Vidal, L., \& Canals, A. (2019). A modified zeolite/iron oxide composite as a sorbent for magnetic dispersive solid-phase extraction for the preconcentration of nonsteroidal anti-inflammatory drugs in water and urine samples. Journal of Chromatography A, 1603, 33-43. Retrieved from https://dx.doi.org/10.1016/j.chroma.2019.06.039 10.1016/j.chroma.2019.06.039

Bansal, O. P. (2013). Chlortetracycline in Illite and Kaolinite Suspensions. Chlortetracycline in Illite and Kaolinite Suspensions, 2013.

Belaib, F., Azzedine, M., Boubeker, B., \& Abdeslam-Hassen, M. (2014). Experimental study of oxytetracycline retention by adsorption onto polyaniline coated peanut shells. Inter- 
national Journal of Hydrogen Energy, 39(3), 1511-1515. Retrieved from https://dx.doi .org/10.1016/j.ijhydene.2013.05.015 10.1016/j.ijhydene.2013.05.015

Bouaziz, Z., Soussan, L., Janot, J.-M., Jaber, M., Amara, A. B. H., \& Balme, S. (2018). Dual role of layered double hydroxide nanocomposites on antibacterial activity and degradation of tetracycline and oxytetracyline. Chemosphere, 206, 175-183. Retrieved from https://dx .doi.org/10.1016/j.chemosphere.2018.05.003 10.1016/j.chemosphere.2018.05.003

Burton, A. (2018). Recent trends in the synthesis of high-silica zeolites. Catal. Rev, 60(1), 132175.

C, C, D., \& Cdc, P. (2020). No Title. Antibiotic / Antimicrobial Resistance (AR / AMR).

Cabildo, D., Claramunt, M., Cornago, R., Escolástico, M., Santos, C., Farrán, S., García, M., López, M., Pérez, C., Pérez, J., María, M. S., \& Sanz, M. (2008). No Title (R. Y. T. de Residuos, EUNED., \& Madrid, Eds.).

Cheng, D. (2019). Contribution of antibiotics to the fate of antibiotic resistance genes in anaerobic treatment processes of swine wastewater: A review. Bioresour. Technol,299, 122654-122654.

Coday, B. D., Xu, P., Beaudry, E. G., Herron, J., Lampi, K., Hancock, N. T., \& Cath, T. Y. (2014). The sweet spot of forward osmosis: Treatment of produced water, drilling wastewater, and other complex and difficult liquid streams. Desalination, 333(1), 23-35. Retrieved from https://dx.doi.org/10.1016/j.desal.2013.11.014 10.1016/j.desal.2013.11.014

Couto, C. F., Lange, L. C., \& Amaral, M. C. (2019). Occurrence, fate and removal of pharmaceutically active compounds (PhACs) in water and wastewater treatment plantsA review. Journal of Water Process Engineering, 32, 100927-100927. Retrieved from https://dx.doi.org/10.1016/j.jwpe.2019.100927 10.1016/j.jwpe.2019.100927

Cristóvão, R. O., Botelho, C. M., Martins, R. J., Loureiro, J. M., \& Boaventura, R. A. (2014). Primary treatment optimization of a fish canning wastewater from a Portuguese plant. Water Resources and Industry, 6, 51-63. Retrieved from https://dx.doi.org/10.1016/ j.wri.2014.07.002 10.1016/j.wri.2014.07.002

Dai, J. (2018). Sustainable bovine bone-derived hierarchically porous carbons with excellent adsorption of antibiotics: Equilibrium, kinetic and thermodynamic investigation. Powder Technol, 331, 162-170.

Dai, Y. (2019). New use for spent coffee ground as an adsorbent for tetracycline removal in water. Chemosphere, 215, 163-172.

Deng, Y., \& Zhao, R. (2015). Advanced Oxidation Processes (AOPs) in Wastewater Treatment. Curr. Pollut. Reports, 1(3), 167-176.

Díaz, I. (2017). Environmental uses of zeolites in Ethiopia. Catal. Today, 285, 29-38.

Eniola, J. O., Kumar, R., Al-Rashdi, A. A., \& Barakat, M. A. (2020). Hydrothermal synthesis of structurally variable binary $\mathrm{CuAl}, \mathrm{MnAl}$ and ternary $\mathrm{CuMnAl}$ hydroxides for oxytetracycline antibiotic adsorption. Journal of Environmental Chemical Engineering, 8(2), 103535-103535. Retrieved from https://dx.doi.org/10.1016/j.jece.2019.103535 10 $.1016 /$ j.jece.2019.103535

Fatta-Kassinos, D., Meric, S., \& Nikolaou, A. (2011). Pharmaceutical residues in environmental waters and wastewater: current state of knowledge and future research. Analytical and Bioanalytical Chemistry, 399(1), 251-275. Retrieved from https://dx.doi.org/10.1007/ s00216-010-4300-9 10.1007/s00216-010-4300-9

Figueroa, R. A., Leonard, A., \& MacKay, A. A. (2004). Modeling Tetracycline Antibiotic Sorption to Clays. Environmental Science \& Technology, 38(2), 476-483. Retrieved from https:// dx.doi.org/10.1021/es0342087 10.1021/es0342087

Gao, Y. (2012). Adsorption and removal of tetracycline antibiotics from aqueous solution by 
graphene oxide. J. Colloid Interface Sci, 368(1), 540-546.

Geissen, V. (2015). Emerging pollutants in the environment: A challenge for water resource management. Int. Soil Water Conserv. Res, 3(1), 57-65.

González-García, P. (2018). Activated carbon from lignocellulosics precursors: A review of the synthesis methods, characterization techniques and applications. Renewable and Sustainable Energy Reviews, 82, 1393-1414. Retrieved from https://dx.doi.org/ 10.1016/j.rser.2017.04.117 10.1016/j.rser.2017.04.117

Gupta, V. K., Agarwal, S., Sadegh, H., Ali, G. A., Bharti, A. K., \& Makhlouf, A. S. H. (2017). Facile route synthesis of novel graphene oxide- $\beta$-cyclodextrin nanocomposite and its application as adsorbent for removal of toxic bisphenol A from the aqueous phase. Journal of Molecular Liquids, 237, 466-472. Retrieved from https://dx.doi.org/10.1016/ j.molliq.2017.04.113 10.1016/j.molliq.2017.04.113

Harja, M., \& Ciobanu, G. (2018). Studies on adsorption of oxytetracycline from aqueous solutions onto hydroxyapatite. Science of The Total Environment, 628-629, 36-43. Retrieved from https://dx.doi.org/10.1016/j.scitotenv.2018.02.027 10.1016/j.scitotenv.2018 .02 .027

Hassan, S. S., Abdel-Shafy, H. I., \& Mansour, M. S. (2019). Removal of pharmaceutical compounds from urine via chemical coagulation by green synthesized ZnO-nanoparticles followed by microfiltration for safe reuse. Arabian Journal of Chemistry, 12(8), 40744083. Retrieved from https://dx.doi.org/10.1016/j.arabjc.2016.04.009 10.1016/j .arabjc.2016.04.009

Huang, L., Shi, C., Zhang, B., Niu, S., \& Gao, B. (2013). Characterization of Activated Carbon Fiber by Microwave Heating and the Adsorption of Tetracycline Antibiotics. Separation Science and Technology, 48(9), 1356-1363. Retrieved from https://dx.doi.org/ 10.1080/01496395.2012.732978 10.1080/01496395.2012.732978

I, N., \& Nih, H. (2020). Antibiotics - Tetracyclines. Antibiotics - Tetracyclines.

Jia, M. (2013). Effects of $\mathrm{pH}$ and metal ions on oxytetracycline sorption to maize-strawderived biochar. Bioresour. Technol, 136, 87-93.

Jiang, N., Shang, R., Heijman, S. G., \& Rietveld, L. C. (2018). High-silica zeolites for adsorption of organic micro-pollutants in water treatment: A review. Water Research, 144, 145-161. Retrieved from https://dx.doi.org/10.1016/j.watres.2018.07.017 10.1016/ j.watres.2018.07.017

Jing, X. R., Wang, Y. Y., Liu, W. J., Wang, Y. K., \& Jiang, H. (2014). Enhanced adsorption performance of tetracycline in aqueous solutions by methanol-modified biochar. Chem. Eng. $J, 248,168-174$.

Król, M., Mozgawa, W., Jastrzębski, W., \& Barczyk, K. (2012). Application of IR spectra in the studies of zeolites from D4R and D6R structural groups. Microporous and Mesoporous Materials, 156, 181-188. Retrieved from https://dx.doi.org/10.1016/j .micromeso.2012.02.040 10.1016/j.micromeso.2012.02.040

Kwon, S., Fan, M., Dacosta, H. F. M., Russell, A. G., Berchtold, K. A., \& Dubey, M. K. (2011). CO2 Sorption. CO2 Sorption.

Li, Z., Schulz, L., Ackley, C., \& Fenske, N. (2010). Adsorption of tetracycline on kaolinite with pH-dependent surface charges. Journal of Colloid and Interface Science, 351(1), 254-260. Retrieved from https://dx.doi.org/10.1016/j.jcis.2010.07.034 10.1016/j .jcis.2010.07.034

Liang, G. (2019). Efficient removal of oxytetracycline from aqueous solution using magnetic montmorillonite-biochar composite prepared by one step pyrolysis. Sci. Total Environ, 695, 133800-133800. 
Liao, P. (2013). Adsorption of tetracycline and chloramphenicol in aqueous solutions by bamboo charcoal: A batch and fixed-bed column study. Chem. Eng. J, 228, 496-505.

Lin, C. C., \& Lee, C. Y. (2019). Adsorption of ciprofloxacin in water using Fe304 nanoparticles formed at low temperature and high reactant concentrations in a rotating packed bed with co-precipitation. Mater. Chem. Phys, 240, 122049-122049.

Lin, D., \& Xing, B. (2008). Adsorption of Phenolic Compounds by Carbon Nanotubes: Role of Aromaticity and Substitution of Hydroxyl Groups. Environmental Science \& Technology, 42(19), 7254-7259. Retrieved from https://dx.doi.org/10.1021/es801297u 10.1021/ es801297u

Lin, Y., Xu, S., \& Li, J. (2013). Fast and highly efficient tetracyclines removal from environmental waters by graphene oxide functionalized magnetic particles. Chem. Eng. J, 225, 679-685.

Liu, M., an Hou, L., Yu, S., Xi, B., Zhao, Y., \& Xia, X. (2013). MCM-41 impregnated with A zeolite precursor: Synthesis, characterization and tetracycline antibiotics removal from aqueous solution. Chemical Engineering Journal, 223, 678-687. Retrieved from https:// dx.doi.org/10.1016/j.cej.2013.02.088 10.1016/j.cej.2013.02.088

Liu, P., Liu, W. J., Jiang, H., Chen, J. J., Li, W. W., \& Yu, H. Q. (2012). Modification of bio-char derived from fast pyrolysis of biomass and its application in removal of tetracycline from aqueous solution. Bioresour. Technol, 121, 235-240.

Luján-Facundo, M. J., Iborra-Clar, M. I., Mendoza-Roca, J. A., \& Alcaina-Miranda, M. I. (2019). Pharmaceutical compounds removal by adsorption with commercial and reused carbon coming from a drinking water treatment plant. Journal of Cleaner Production, 238, 117866-117866. Retrieved from https://dx.doi.org/10.1016/j.jclepro.2019.117866 10.1016/j.jclepro.2019.117866

Ma, C. (2018). Honeycomb tubular biochar from fargesia leaves as an effective adsorbent for tetracyclines pollutants. J. Taiwan Inst. Chem. Eng, 91, 299-308.

Mashkoor, F., Nasar, A., \& Inamuddin. (2020). Carbon nanotube-based adsorbents for the removal of dyes from waters: A review. Environmental Chemistry Letters, 18(3), 605-629. Retrieved from https://dx.doi.org/10.1007/s10311-020-00970-6 10.1007/ s10311-020-00970-6

Mercier, J. P., Zambelli, G., \& Kurz, W. (2012). Introduction to materials science. In and others (Ed.), . Elsevier Science.

Mohammed, A. A., \& Kareem, S. L. (2019). Adsorption of tetracycline fom wastewater by using Pistachio shell coated with $\mathrm{ZnO}$ nanoparticles: Equilibrium, kinetic and isotherm studies. Alexandria Engineering Journal, 58(3), 917-928. Retrieved from https://dx.doi .org/10.1016/j.aej.2019.08.006 10.1016/j.aej.2019.08.006

Nguyen, C. H., Fu, C.-C., Kao, D.-Y., Tran, T. T. V., \& Juang, R.-S. (2020). Adsorption removal of tetracycline from water using poly(vinylidene fluoride)/polyaniline-montmorillonite mixed matrix membranes. Journal of the Taiwan Institute of Chemical Engineers, 112, 259-270. Retrieved from https://dx.doi.org/10.1016/j.jtice.2020.06.007 10.1016/j .jtice.2020.06.007

Noreen, U. (2019). Water pollution and occupational health hazards caused by the marble industries in district Mardan. Environ. Technol. Innov, 16, 100470-100470.

Nowack, B., \& Bucheli, T. D. (2007). Occurrence, behavior and effects of nanoparticles in the environment. Environmental Pollution, 150(1), 5-22. Retrieved from https://dx.doi .org/10.1016/j.envpol.2007.06.006 10.1016/j.envpol.2007.06.006

Oladoja, N. A., Adelagun, R. O. A., Ahmad, A. L., Unuabonah, E. I., \& Bello, H. A. (2014). Preparation of magnetic, macro-reticulated cross-linked chitosan for tetracycline removal 
from aquatic systems. Colloids and Surfaces B: Biointerfaces, 117, 51-59. Retrieved from https://dx.doi.org/10.1016/j.colsurfb.2014.02.006 10.1016/j.colsurfb.2014.02.006

Pancorbo-Mendoza, J., \& Zegarra-Del-Carpio, R. (2004). Antibióticos sistémicos en dermatología. Dermatologia Peru, 14(7), 161-179.

Papa, E. (2018). Zeolite-geopolymer composite materials: Production and characterization. J. Clean. Prod, 171, 76-84.

Park, S.-M., Alessi, D. S., \& Baek, K. (2019). Selective adsorption and irreversible fixation behavior of cesium onto 2:1 layered clay mineral: A mini review. Journal of Hazardous Materials, 369, 569-576. Retrieved from https://dx.doi.org/10.1016/j.jhazmat.2019 02.061 10.1016/j.jhazmat.2019.02.061

Percival, S. L., Bowler, P. G., \& Russell, D. (2005). Bacterial resistance to silver in wound care. Journal of Hospital Infection, 60(1), 1-7. Retrieved from https://dx.doi.org/10.1016/ j.jhin.2004.11.014 10.1016/j.jhin.2004.11.014

Pham, T. D., Tran, T. T., Le, V. A., Pham, T. T., Dao, T. H., \& Le, T. S. (2019). Adsorption characteristics of molecular oxytetracycline onto alumina particles: The role of surface modification with an anionic surfactant. J. Mol. Liq, 287, 110900-110900.

Piai, L., Dykstra, J. E., Adishakti, M. G., Blokland, M., Langenhoff, A. A., \& van der Wal, A. (2019). Diffusion of hydrophilic organic micropollutants in granular activated carbon with different pore sizes. Water Research, 162, 518-527. Retrieved from https://dx.doi.org/ 10.1016/j.watres.2019.06.012 10.1016/j.watres.2019.06.012

Raeiatbin, P., \& Açıkel, Y. S. (2017). Removal of tetracycline by magnetic chitosan nanoparticles from medical wastewaters. DESALINATION AND WATER TREATMENT, 73, 380388. Retrieved from https://dx.doi.org/10.5004/dwt.2017.20421 10.5004/dwt.2017 .20421

Rao, A. K., Müller, C. N. R., \& Cheetham, A. (2004). The Chemistry of Nanomaterials. The Chemistry of Nanomaterials: Synthesis, Properties and Applications.

Rattanachueskul, N., Saning, A., Kaowphong, S., Chumha, N., \& Chuenchom, L. (2017). Magnetic carbon composites with a hierarchical structure for adsorption of tetracycline, prepared from sugarcane bagasse via hydrothermal carbonization coupled with simple heat treatment process. Bioresource Technology, 226, 164-172. Retrieved from https://dx.doi.org/10.1016/j.biortech.2016.12.024 10.1016/j.biortech.2016.12.024

Rivera-Utrilla, J., Gómez-Pacheco, C. V., Sánchez-Polo, M., López-Peñalver, J. J., \& OcampoPérez, R. (2013). Tetracycline removal from water by adsorption/bioadsorption on activated carbons and sludge-derived adsorbents. Journal of Environmental Management, 131, 16-24. Retrieved from https://dx.doi.org/10.1016/j.jenvman.2013.09.024 10.1016/j.jenvman.2013.09.024

Ruff, M., Mueller, M. S., Loos, M., \& Singer, H. P. (2015). Quantitative target and systematic non-target analysis of polar organic micro-pollutants along the river Rhine using high-resolution mass-spectrometry - Identification of unknown sources and compounds. Water Research, 87, 145-154. Retrieved from https://dx.doi.org/10.1016/ j.watres.2015.09.017 10.1016/j.watres.2015.09.017

Saha, P., \& Chowdhury, S. (2011). Insight Into Adsorption Thermodynamics. Thermodynamics.

Saman, N., Othman, N. S., Chew, L.-Y., Setapar, S. H. M., \& Mat, H. (2020). Cetyltrimethylammonium bromide functionalized silica nanoparticles (MSN) synthesis using a combined sol-gel and adsorption steps with enhanced adsorption performance of oxytetracycline in aqueous solution. Journal of the Taiwan Institute of Chemical Engineers, 112, 67-77. Retrieved from https://dx.doi.org/10.1016/j.jtice.2020.07.008 10.1016/ 


\section{j.jtice.2020.07.008}

Santaeufemia, S., Torres, E., Mera, R., \& Abalde, J. (2016). Bioremediation of oxytetracycline in seawater by living and dead biomass of the microalga Phaeodactylum tricornutum. Journal of Hazardous Materials, 320, 315-325. Retrieved from https://dx.doi.org/10 .1016/j.jhazmat.2016.08.042 10.1016/j.jhazmat.2016.08.042

Sharififard, H., shahraki, Z. H., Rezvanpanah, E., \& Rad, S. H. (2018). A novel natural chitosan/activated carbon/iron bio-nanocomposite: Sonochemical synthesis, characterization, and application for cadmium removal in batch and continuous adsorption process. Bioresource Technology, 270, 562-569. Retrieved from https://dx.doi.org/ 10.1016/j.biortech.2018.09.094 10.1016/j.biortech.2018.09.094

Smith, J., \& Hashemi, W. (2006). Fundamentos de la ciencia e ingeniería de materiales. Fundamentos de la ciencia e ingeniería de materiales.

Song, X., Liu, D., Zhang, G., Frigon, M., Meng, X., \& Li, K. (2014). Adsorption mechanisms and the effect of oxytetracycline on activated sludge. Bioresour. Technol, 151, 428-431.

Soori, M. M., Ghahramani, E., Kazemian, H., Al-Musawi, T. J., \& Zarrabi, M. (2016). Intercalation of tetracycline in nano sheet layered double hydroxide: An insight into UV/VIS spectra analysis. Journal of the Taiwan Institute of Chemical Engineers, 63, 271-285. Retrieved from https://dx.doi.org/10.1016/j.jtice.2016.03.015 10.1016/j.jtice.2016.03.015

Taheran, M., Naghdi, M., Brar, S. K., Knystautas, E. J., Verma, M., Ramirez, A. A., Surampalli, R. Y., \& Valero, J. R. (2016). Adsorption study of environmentally relevant concentrations of chlortetracycline on pinewood biochar. Science of The Total Environment, 571, 772777. Retrieved from https://dx.doi.org/10.1016/j.scitotenv.2016.07.050 10.1016/j .scitotenv.2016.07.050

Vicente, D., \& Pérez-Trallero, E. (2010). Tetraciclinas, sulfamidas y metronidazol. Enfermedades Infecciosas y Microbiología Clínica, 28(2), 122-130. Retrieved from https:// dx.doi.org/10.1016/j.eimc.2009.10.002 10.1016/j.eimc.2009.10.002

Vu, B. K., Shin, E. W., Snisarenko, O., Jeong, W. S., \& Lee, H. S. (2010). Removal of the antibiotic tetracycline by Fe-impregnated SBA-15. Korean Journal of Chemical Engineering, 27(1), 116-120. Retrieved from https://dx.doi.org/10.1007/s11814-009-0313-5 10.1007/ s11814-009-0313-5

Vu, B. K., Snisarenko, O., Lee, H. S., \& Shin, E. W. (2010). Adsorption of tetracycline on La-impregnated MCM-41 materials. Environmental Technology, 31(3), 233241. Retrieved from https://dx.doi.org/10.1080/09593330903453210 10.1080/ 09593330903453210

Wang, H. (2018). Sorption of tetracycline on biochar derived from rice straw and swine manure. RSC Adv, 8(29), 16260-16268.

Wang, Y. J., Sun, R. J., Xiao, A. Y., Wang, S. Q., \& Zhou, D. M. (2010). Phosphate affects the adsorption of tetracycline on two soils with different characteristics. Geoderma, 156(34), 237-242.

Worch, E. (2012). adsorption Technology in Water Treatment. Adsorption Technology in Water Treatment.

Wu, J., Wang, Y., Wu, Z., Gao, Y., \& Li, X. (2020). Adsorption properties and mechanism of sepiolite modified by anionic and cationic surfactants on oxytetracycline from aqueous solutions. Sci. Total Environ, 708, 134409-134409.

Xiong, W., Ni, P., Chen, Y., Gao, Y., Li, S., \& Zhan, A. (2019). Biological consequences of environmental pollution in running water ecosystems: A case study in zooplankton. Environmental Pollution, 252, 1483-1490. Retrieved from https://dx.doi.org/10.1016/ j.envpol.2019.06.055 10.1016/j.envpol.2019.06.055 
Yagub, M. T., Sen, T. K., Afroze, S., \& Ang, H. M. (2014). Dye and its removal from aqueous solution by adsorption: A review. Advances in Colloid and Interface Science, 209, 172184. Retrieved from https://dx.doi.org/10.1016/j.cis.2014.04.002 10.1016/j.cis.2014 .04 .002

Yu, J. G. (2014). Aqueous adsorption and removal of organic contaminants by carbon nanotubes. Sci. Total Environ(1), 241-251.

Yuan, L. (2019a). Influences of $\mathrm{pH}$ and metal ions on the interactions of oxytetracycline onto nano-hydroxyapatite and their co-adsorption behavior in aqueous solution. J. Colloid Interface Sci, 541, 101-113.

Yuan, L. (2019b). Influences of $\mathrm{pH}$ and metal ions on the interactions of oxytetracycline onto nano-hydroxyapatite and their co-adsorption behavior in aqueous solution. J. Colloid Interface Sci, 541, 101-113.

Zaher, A., Taha, M., Farghali, A. A., \& Mahmoud, R. K. (2020). Zn/Fe LDH as a clay-like adsorbent for the removal of oxytetracycline from water: combining experimental results and molecular simulations to understand the removal mechanism. Environmental Science and Pollution Research, 27(11), 12256-12269. Retrieved from https://dx.doi.org/ 10.1007/s11356-020-07750-3 10.1007/s11356-020-07750-3

Zaher, A., Taha, M., \& Mahmoud, R. K. (2021). Possible adsorption mechanisms of the removal of tetracycline from water by La-doped Zn-Fe-layered double hydroxide. Journal of Molecular Liquids, 322, 114546-114546. Retrieved from https://dx.doi.org/10.1016/ j.molliq.2020.114546 10.1016/j.molliq.2020.114546

Zhang, B. (2013). Synthesis of BSA/Fe304 magnetic composite microspheres for adsorption of antibiotics. Mater. Sci. Eng. C, 33(7), 4401-4408.

Zhang, H. (2018). Enhanced adsorption of oxytetracycline to weathered microplastic polystyrene: Kinetics, isotherms and influencing factors. Environ. Pollut, 243, 15501557.

Zhang, L., Song, X., Liu, X., Yang, L., Pan, F., \& Lv, J. (2011). Studies on the removal of tetracycline by multi-walled carbon nanotubes. Chem. Eng. J, 178, 26-33.

Zhang, L., Yao, L., Ye, L., Long, B., Dai, Y., \& Ding, Y. (2020). Benzimidazole-based hyper-crosslinked polymers for effective adsorption of chlortetracycline from aqueous solution. J. Environ. Chem. Eng, 8(6), 104562-104562.

Zhang, X., Lin, X., He, Y., \& Luo, X. (2019). Phenolic hydroxyl derived copper alginate microspheres as superior adsorbent for effective adsorption of tetracycline. Int. J. Biol. Macromol, 136, 445-459.

Zhang, Y. (2017). Removal of tetracycline and oxytetracycline from water by magnetic Fe304@graphene. Environ. Sci. Pollut. Res, 24(3), 2987-2995.

Zhou, H., \& Smith, D. W. (2001). Advanced technologies in water and wastewater treatment," Can. J. Civ. Eng, 28(S1), 49-66.

Zhou, Q., Li, Z., Shuang, C., Li, A., Zhang, M., \& Wang, M. (2012). Efficient removal of tetracycline by reusable magnetic microspheres with a high surface area. Chem. Eng. J, 210, 350356.

Zou, Y. L., Huang, H., Chu, M., Lin, J. W., Yin, D. Q., \& Li, Y. N. (2012). Adsorption Research of Tetracycline from Water by HCl-Modified Zeolite. Advanced Materials Research, 573574, 43-47. Retrieved from https://dx.doi.org/10.4028/www.scientific.net/amr.573 -574.43 10.4028/www.scientific.net/amr.573-574.43 